talt tilbage $\mathrm{i}$ tiden for at følge $\varnothing_{\mathrm{r}-}$ steds begivenhedsrige rejse gennem livet og undervejs nyde de smukke billeder.

POUL DUEDAHL

\section{Darwins kamp for overlevelse}

Charles Darwin: Menneskets afstamning ogparringsvalget, oversat af J. P. Jacobsen, bearbejdet af Lotte Langer, introduktion ved Hans Henrik Hjermitslev, Husets Forlag, 2009, 488 sider, 399,- kr.

Darwin-industrien lever i bedste velgående. Hvis nogen overhovedet skulle have været $i$ tvivl, så burde de ikke være det i kølvandet på fejringen af 200-året for Charles Darwins fødsel i det forgangne år. En fejring der selvfølgelig har været fuldt ud berettiget i betragtning af, at hans epokegørende tanker i store træk stadig holder vand; for ikke at tale om hovedværkernes virkningshistorie, der er helt unik for ikkereligiøse skrifter og som kun vanskeligt kan overvurderes.

Men hvad der måske har manglet ind imellem de mange publikationer og fjernsynsudsendelser om Darwins liv og udlægningerne af hans tanker og ideer, er Darwin selv - altså mandens egne ord og dermed selve omdrejningspunktet for de mange fortolkninger. For det er som om Darwin-forskningen har fået sit helt eget liv uden om værkerne; en tendens der næppe vil blive mindre $\mathrm{i}$ årene fremover, $\mathrm{da}$ fortolkningerne jo også har deres helt egen virkningshistorie. Darwin er med andre ord ved at blive udkonkurreret af sin egen succes.

Så meget desto mere befriende er det, at Husets Forlag har påtaget sig opgaven med at give manden selv et talerør med genudgivelsen af hans andet hovedværk, nemlig det om menneskets afstamning og parringsvalget. Ikke af originalen, The Descent of Man, and Selection in Relation to Sex fra 1871, men af J.P. Jacobsens oversættelse fra 1875. Det er faktisk ikke nogen uvæsentlig pointe. Selvom der stadig mangler et indgående studie af, hvor de to værker sprogligt og indholdsmæssigt afviger fra hinanden, så er det ganske givet, at det er Darwins ord gennem netop J.P. Jacobsens stemme, der har sat sig de største spor i dansk åndsliv.

Forlaget og redaktørerne har simpelthen gjort J.P. Jacobsen tilgængelig igen. Ikke blot ved at udgive værket som bog og e-bog, men i lige så høj grad ved igen at gøre værket læseligt. Det vil sige i form af en sproglig bearbejdning af datidens retstavning, der jo for mange nutidsmennesker alene udgør et forstyrrende element. Forsøget på 
at gøre Darwin mere sexet er dog udført nænsomt og altså uden at fjerne alle de undertiden lettere bedagede begreber og bestanddele, som netop gør værket historisk. Det gælder selvfølgelig især de politisk ukorrekte elementer $\mathrm{i}$ form af Darwins anvendelse af det nu stærkt kontroversielle racebegreb og hans hierarkisering af menneskehedens kulturer. Elementer som jo viser, at han i høj grad selv lagde grobunden for den socialdarwinisme, som andre siden hen og også med nogen ret - er blevet klandret for. Den slags opdelinger i f.eks. "vilde", "halvciviliserede" og "civiliserede" medborgere hørte nemlig tiden til og har haft mindst lige så omfattende følgevirkninger som de mindre omdiskuterede og videnskabeligt holdbare elementer i værket.

Uanset hvilken udgave man læser er det essentielle i værket dog stadig Darwins banebrydende forsøg på at udlægge menneskets afstamning. Budskabet var og er, at menneskene følger de samme arvelighedslove som resten af dyreriget og er resultatet af en langstrakt udviklingshistorie. Størstedelen af værket er dog helliget den såkaldte seksuelle selektion i et forsøg på at føre beviset og er da også en grundig indføring $i$, hvordan hanner og hunner promoverer og fremhæver eventuelle fortrin - bl.a. dem, der som påfuglefjer synes aldeles unyttige, men som jo bl.a. indikerer sundhedstilstand og styrke - for at tiltrække sig hinandens opmærksomhed og som derved driver evolutionen frem. Om disse hovedbestanddele er der bare at sige: Læs dem selv!

Men værket er selvfølgelig meget mere end det. Det var f.eks. et opgør med samtidens gængse tilgang til antropologien, hvis udøvere havde en tendens til at se menneskene som konstante former, hvor Darwin altså så dem som nogle, der forandrede sig jæunt fremad som følge af naturlig udvælgelse i den fortsatte overlevelseskamp for at skaffe mad og partner i en verden, hvor kun de kvalitativt bedste havde succes. Værket havde altså en særlig målgruppe. Dertil kommer en mængde andre temmelig tidsspecifikke dagsordener, som det kræver visse forudsætninger at gennemskue.

Heldigvis er den nye genudgivelse forsynet med en kort, men yderst velskrevet og informativ indføring i værkets tilblivelse, hovedindhold og virkningshistorie udformet af videnskabshistorikeren Hans Henrik Hjermitslev fra Aarhus Universitet. Indledningen klæder læseren tilstrækkeligt godt på til den opgave, som det trods alt stadig er at forstå budskabet i Darwins tanker og enkeltdelene i hans værk. 
Skulle man få lyst til at supplere den med andre forskeres bud på en udlægning af Darwins værker, så kan man jo altid gå på jagt i nærværende tidsskrift, da Slagmark i foråret 2009 udgav et temanummer (nr. 54) om darwinisme.

MIKKEL THORUP

\section{Traktat om de tre bedragere}

Anonym: Traktat om de tre bedragere, oversat af Claus Bratt Østergaard, forord ved Frederik Stjernfelt, Informations Forlag, 2010, 176 sider, 199,- kr.

Det er et ofte hørt argument fra religiøse for religion, at der altid har været folk, der troede på noget guddommeligt. At tro altså er noget mennesket iboende. Argumentationen kan dog vendes om, idet der på samme tid også altid har eksisteret skeptikere, agnostikere, fritænkere og ateister. De har bare sjældnere efterladt sig skriftlige, rituelle, ikoniske, institutionelle eller arkitektoniske vidnesbyrd, ikke mindst fordi det $\mathrm{i}$ sandhed er en transhistorisk sandhed, at den religionskritiske eller religionsløse er blevet forfulgt af den religiøse.

Det er også vilkåret for denne anonymt udgive tekst, der tilsyneladende er startet som et rygte (og som bagvaskelse af dem, religiøse og politiske magter har villet delegitimere) for på et tidspunkt at manifestere sig som det, teksten blev beskyldt for at være, før den endnu eksisterede som faktisk tekst, nemlig som en rasende anklage imod den religiøse undertrykkelse. Traktaten er ikke et angreb på religion som sådan. Teksten selv synes at have et panteistisk grundsyn. Men den er et frontalangreb på religionsstiftere og på alle, som bruger religion til at undertrykke andre med. Den er ikke sofistikeret, men dog belæst.

Bogens forord af Frederik Stjernfelt opruller på fornem vis tekstens mysteriøse ophav, de mange rygter om den, diskussionerne om dens forfatter(e) samt den publicerings- og receptionshistoriske vigtige pointe om forholdene for publicering af den slags litteratur samt faren ved at læse, eje og forholde sig til den. Det er et vigtigt forhold ved megen af den litteratur, vi som idéhistorikere arbejder med, at de kun kunne udgives anonymt, at der skulle bedrag, mod og smugleri til for at udbrede dem, og at teksterne ofte blev kopieret, ændret og forfalsket af andre, således at selve forestillingen om forfatteren og budskabet i deres strenge forstand bliver anstrengt eller decideret meningsløs. Her har vi en tekst, hvis afsender eller snarere 